\title{
PENGARUH PENGGUNAAN MEDIA WHATSAPP TERHADAP KINERJA KARYAWAN
}

\author{
Musdalifah $^{1)}$ dan Rini Koen Iswandari ${ }^{2)}$ \\ ${ }^{1,2}$ Jurusan Pariwisata, Politeknik Negeri Samarinda \\ 1,2 Ciptomangun Kusumo Samarinda \\ E-mail : lmusda14@yahoo.co.id ${ }^{1)}$, klenting2003@yahoo.com ${ }^{2)}$
}

\begin{abstract}
ABSTRAK
Penelitian ini bertujuan untuk mengetahui pengaruh penggunaan media whatsapp terhadap kinerja karyawan di lingkungan Politeknik Negeri Samarinda. Responden dalam penelitian ini sebanyak 70 orang yang terdiri dari staff pengajar (dosen) maupun tenaga kependidikan. Data dalam penelitian ini dikumpulkan dengan menyebarkan kuisioner secara online menggunakan google form. Penelitian ini menggunakan satu variabel bebas yaitu penggunaan media whatsapp yang menggunakan indikator pengetahuan, penggunaan dan manfaat. Sedangkan variabel terikat kinerja karyawan diukur dengan menggunakan indikator kualitas, kuantitas, ketepatan waktu, efektifitas biaya dan hubungan antar personal. Hasil penelitian ini menunjukkan bahwa penggunaan media whatsapp berpengaruh terhadap kinerja karyawan. Penyampaian informasi menggunakan whatsapp mudah untuk dilakukan sehingga dapat dilakukan koordinasi yang terkait dengan pekerjaan. Whatsapp merupakan media yang paling sering digunakan baik dalam hal pekerjaan maupun secara personal.
\end{abstract}

Kata kunci: Kinerja, Pengaruh, Whatsapp, Karyawan

\section{PENDAHULUAN}

Whatsapp sebagai salah satu media sosial saat ini banyak yang digunakan untuk bersosialisasi dalam hal penyampaian pesan baik oleh individu maupun kelompok. Penggunaan media ini tidak hanya sebatas pada keperluan pribadi saja namun juga dapat digunakan untuk menunjang pekerjaan. Secara khusus di masa pandemi ini dimana setiap kegiatan yang terkait dengan pekerjaan yang mengharuskan untuk tidak melakukan pertemuan secara langsung sehingga salah satu alternatif yang dapat digunakan adalah dengan menggunakan media whatsapp. Pada dasarnya penggunaan media ini memiliki dampak yang positif dan negatif. Banyak hal positif yang dirasakan oleh penggunanya Namun tidak sedikit dampak negatif yang timbul dari penggunaan whatsapp oleh penggunanya. Terkait dengan dampak yang timbul maka dalam penelitian ini ingin menggali sejauh mana penggunaan media whatsapp memiliki pengaruh terhadap kinerja karyawan.

Media whatsapp ini menyediakan banyak fitur, mulai dari mengirim pesan teks seperti halnya mengirim SMS, menyimpan dan menghapus pesan serta dapat langsung mengirim pesan sebelumnya atau pesan masuk kepada lain tanpa harus mengetik ulang. Selain itu whatsapp juga dalam melakukan percakapan secara personal maupun dalam grup sehingga memudahkan dalam penyampaian pesan. Tidak terbatas pada hal yang telah diungkapkan sebelumnya, media ini juga dapat mengirim dan menerima gambar atau file lain yang berbentuk pdf, word maupun excel.

Penelitian sebelumnya yang berjudul "Analisis Pengaruh Aplikasi Whatsapp terhadap Kinerja Karyawan pada PT First Position Group' menunjukkan bahwa penggunaan whatsapp memiliki pengaruh terhadap kinerja karyawan (Jati, 2016). Penggunaan media whatsapp dapat dimanfaatkan untuk membuat hasil kerja yang lebih maksimal. Namun lain halnya

pada penelitian yang berjudul "efektifitas Komunikasi Melalui Aplikasi Whatsapp (Studi Terhadap Group KPI 2012" yang menunjukkan bahwa adanya ketidakpuasan dalam berkomunikasi dengan menggunakan aplikasi media whatsapp sehingga dalam penelitian menunjukkan hasil yang berbeda dari penelitian sebelumnya yang telah diungkapkan (Wahyuni, 2016) .

Kepuasan merupakan aspek yang dibutuhkan sehingga pada saat menggunakan whatsapp dalam berkomunikasi dapat dirasakan manfaatnya oleh penggunanya. Sejalan dengan halnya karyawan yang mengutamakan aspek kepuasan dalam penggunaan whatsapp dalam lingkungan kerja yang memiliki dampak pada hasil kerja.

Penelitian yang berjudul "Pengaruh Whatsapp terhadap Perilaku Tertutup Mahasiswa (Survey Pada Mahasiswa Ilmu Komunikasi FISHUM Universitas Islam Negeri Sunan Kalijaga Yogyakarta Angkatan 2014) menunjukkan hasil bahwa whatsapp merupakan media yang dapat memudahkan dalam melakukan komunikasi dan juga berdampak perilaku mahasiswa yang menjadi lebih tertutup. Hal ini mengandung pengertian bahwa komunikasi yang terjalin lebih banyak menggunakan media daripada secara langsung sehingga interaksi yang terjadi secara langsung jarang dan bahkan sulit untuk terjadi sehingga hal ini lah yang membuat menjadi lebih tertutup. (Arifin, 2015). 
Peran whatsapp mampu menjembatani informasi yang terputus maupun lamban dengan memaksimalkan group yang ada dan mengembangkan silaturahmi yang berbasis informasi kampus. Beberapa pengajar dan mahasiswa memanfaatkan whatsapp sebagai bagian dari media yang mampu berinteraksi langsung terhadap perkuliahan (Sukrillah, 2018).

Alasan yang menjadi hambatan-hambatan komunikasi akan berpengaruh dalam berkomunikasi. Hambatan komunikasi terjadi karena adanya perbedaan pola pikir yang disebabkan oleh pengalaman, latar pendidikan bahkan usia yang berbeda dan beragam antar karyawan. Keberagaman karyawan menjadi tantangan sendiri dalam mengatasi masalah pada gangguan proses komunikasi dan dapat mempengaruhi sikap kerja karyawan yang memungkinkan berdampak pada hasil kerjanya (Kusuma, 2013).

Berdasarkan hasil penelitian yang telah dilakukan sebelumnya yang menunjukkan adanya perbedaan, maka peneliti melakukan penelitian kembali dengan menggunakan variabel penelitian yang sama namun dilakukan pada objek penelitian yang berbeda.

\section{RUANG LINGKUP}

Dalam penelitian ini permasalahan mencakup :

1. Cakupan permasalahan

Permasalahan dalam penelitian ini mengenai pengaruh penggunaan media whatsapp terhadap kinerja karyawan pada Politeknik Negeri Samarinda

2. Batasan penelitian

Pada penelitian ini dibatasi pada bahasan tentang pengaruh penggunaan media whatsapp terhadap kinerja karyawan yang ada di Politeknik Negeri Samarinda

3. Rencana hasil yang didapatkan

Hasil yang diperoleh dari penelitian ini adalah diduga penggunaan media whatsapp berpengaruh terhadap kinerja karyawan

\section{BAHAN DAN METODE}

Pada bagian ini memuat mengenai kajian teoritis dan tahapan penelitian

\subsection{Whatsapp}

Saat sekarang hampir semua web berbasis interaktif dan memungkinkan pertukaran pesan dalam jarak jauh ini. Media sosial yang kian mewabah didunia (Twitter, Facebook, Path, Instagram, Line, Whatsaap) adalah beberapa contoh fasilitas pengiriman pesan yang dimaksud (Arifianto, 2017).

Whatsapp adalah media sosial berbentuk aplikasi chating yang dapat digunakan di smartphone dan hampir mirip BlackBerry Messenger. Media sosial Whatsapp adalah aplikasi pesan instant yang berfungsi untuk mengirim dan menerima pesan, tanpa dikenakan biaya pulsa seperti SMS dan Telepon seluler. Hal ini dikarenakan whatsapp menggunakan paket data internet yang sama dengan aplikasi lainnya. Jaringan data internet yang diperlukan untuk menjalankan aplikasi whatsapp ialah koneksi $3 G$ atau WiFi. Fitur- fitur yang dapat digunakan pada whatsapp yaitu, melakukan personal /group chat ketepatan waktu (timelines) dan efektivitas biaya (cost effectiviness).

Adapun beberapa fitur yang dimiliki whatsapp, antara lain sebagai berikut :

1. Mengirim dan menerima pesan teks maupun suara

2. Menerima dan mengirim foto yang diambil langsung melalui kamera maupun yang berada di galerry HP

3. Mengirim video

4. Mengirim dan menerima dokumen (word, excel, pdf)

5. Dapat melakukan penggilan telepon dan panggilan video.

6. Share location memanfaatkan GPS

7. Menerima dan mengirim kontak yang ada

8. Dapat menambahkan ataupun bertukar emoticon baik secara personal maupun melalui whatsapp group

9. Dapat membuat foto profil maupun status

10. Mengatur privasi dalam menggunakan whatsapp pada fitur pengaturan (Rusni, 2017).

Whatsapp memiliki beberapa kelebihan yaitu (Rusni, 2017) :

1. Aplikasi whatsapp dapat diunduh dengan mudah tanpa menggunakan

2. Dapat mengirim dan menerima pesan, gambar, video, audio dan pesan suara dengan mudah.

3. Dapat melakukan obrolan dengan orang lain dengan kuota lebih dari 70 orang dalam satu chat group.

4. Menggunakan data yang lebih kecil dibandingkan aplikasi lainnya

Dalam menggunakan sebuah produk terdapat faktorfaktor yang bisa mempengaruhi dalam menggunakannya, yang dimaksud adalah whatsapp. Faktor-faktor tersebut diantaranya (Nitisusastro, 2012):

1. Pengetahuan Tentang Karakteristik atau ciri khas. Pengetahuan tersebut terdiri dari segala tentang whatsapp, mulai dari cara mengunduh dan penggunaannya.

2. Manfaat

Mengetahui kelebihan dan kelemahan yang dimilik whatsapp dibanding aplikasi lain yang serupa.

3. Penggunaan

Penggunaan whatsapp lebih efisien Ketika tersambung internet.

\subsection{Kinerja Karyawan}

Kinerja adalah hasil kerja yang dapat dicapai oleh seseorang atau kelompok orang dalam suatu perusahaan sesuai dengan wewenang dan tanggung jawab masingmasing dalam upaya pencapaian tujuan organisasi secara ilegal, tidak melanggar hukum dan tidak bertentangan dengan moral dan etika (Afandi, 2018).

Beberapa kriteria untuk menilai kinerja karyawan sebagai berikut (Bernardin, 2016) : 
1. Kualitas (Quality) adalah mutu dari pekerjaan yang dilakukan.

2. Kuantitas (Quantity) adalah jumlah dari pekerjaan yang dilakukan

3. Ketepatan waktu (Timeliness) merupakan kegiatan yang dilakukan sesuai target waktu yang telah ditetapkan.

4. Efektivitas biaya (Cost effectiveness) adalah memaksimalkan keuntungan dengan cara melakukan efisiensi biaya namun tidak mengurangi mutu yang dihasilkan.

5. Hubungan antar perseorangan (interpersonal impact) merupakan hubungan kerjasama yang dilakukan baik atar sesama karyawan maupun dengan atasan serta saling menghargai satu sama lain.

\subsection{Penelitian terdahulu}

Beberapa penelitian terdahulu yang menggunakan variabel penggunaan media whatsapp dan kinerja karyawan diantaranya adalah:

1. Pengaruh Komunikasi melalui Grup Whatsapp untuk Meningkatkan Kinerja Karyawan di Hotel Grandhika Medan. Hasil penelitian ini menunjukkan bahwa kinerja yang ada pada karyawan di Hotel Grandhika Setia budi Medan menjadi lebih baik karena sangat membantu dengan menggunakan grup whatsapp informasi lebih cepat sampai tanpa harus membuang waktu untuk ke sana kemari demi mendapatkan informasi yang akan disampaikan dan didapatkan atau penyampaian pesan lebih mudah. Terlebih whatsapp sangat membantu dalam promosi penjualan kepada konsumen-konsumen lainnya. Terdapatnya Pengaruh Komunikasi melalui grup whatsApp untuk meningkatkan kinerja karyawan di Hotel Grandhika Setiabudi Medan sebesar 0.627 Hubungannya yaitu cukup sangat berarti dimana whatsApp sangat membantu dalam penyampaian informasi ataupun mendapatkan informasi baik berupa pesan maupun suara terlebih memiliki grup dimana semua rekan kerja bergabung di dalamnya sehingga lebih memudahkan untuk penyampaian pesan karena lebih cepat diterima team dan whatsApp juga alat yang baik dalam promosi penjualanan dikarenakan sekarang zaman online semua lebih mudah dalam genggaman (Sihombing, 2017).

2. Penggunaan Media Komunikasi Whatsapp terhadap Efektivitas Kinerja Karyawan. Hasil penelitian ini menunjukkan bahwa penggunaan media komunikasi whatsapp terbukti mempengaruhi kinerja karyawan. Terdapat hubungan antara kedua variabel tersebut, berdasarkan interpretasi terhadap koefisien korelasi tingkat hubungannya termasuk pada kategori Kuat pada nilai 0,756 dengan standar deviasi 1 persen (Anjani, 2018).

3. Pengaruh Penggunaan Teknologi Informasi, Kompleksitas Tugas, dan Lingkungan kerja terhadap Kinerja Pegawai. Berdasarkan hasil analisis deskriptif varaibel penggunaan teknologi informasi, lingkungan kerja dan kinerja dalam kriteria baik sedangkan kompleksitas tugas pegawai dalam tingkat sedang. Penggunaan teknologi informasi dan lingkungan kerja berpengaruh signifikan terhadap kinerja pegawai dengan hasil koefisien regresi bertanda positif, hal ini berarti semakin baik penggunaan teknologi informasi dan lingkungan kerja dari pegawai maka kinerja pegawai juga akan mengalami peningkatan. Kompleksitas tugas berpengaruh signifikan terhadap kinerja pegawai dengan nilai koefisien regresi bertanda negatif, hal ini berarti bahwa semakin banyak atau semakin tinggi kompleksitas yang dilakukan pegawai maka dapat menurunkan kinerja pegawai itu sendiri (Rofano, 2019).

\subsection{Metode Penelitian/Tahapan Penelitian}

Penelitian ini dilakukan dengan menyebarkan kuisioner yang memuat daftar pertanyaan/pernyataan mengenai variabel yang diteliti dalam penelitian ini yaitu penggunaan whatsapp dan kinerja karyawan. Kuisioner disebarkan kepada para pegawai yang berada di lingkungan Politeknik Negeri Samarinda. Kuisioner ini disebar secara online dikarenakan adanya pandemi Covid-19 maka untuk mengurangi resiko penyebaran virus tersebut, melalui whatsapp group maupun menggunakan secara personal. Kuisioner yang terkumpul sebanyak 70 orang responden. Sampel yang diambil menggunakan purposive sampling. Menurut Roscoe bahwa secara umum dalam menentukan jumlah ukuran sampel salah satunya adalah lebih dari 30 dan kurang dari 500 (Sugiyono 2012).

Tahapan dalam menganalisis data dalam penelitian ini adalah :

1. Melakukan uji validitas dimaksudkan untuk mengukur sejauh mana instrument yang digunakan benar-benar mengukur yang seharusnya diukur . Suatu alat ukur dikatakan mempunyai validitas tinggi jika alat ukur tersebut menjalankan fungsi ukurnya.

2. Melakukan uji reabilitas (reability) suatu pengukur menunjukkan akurasi, konsistensi dan ketepatan dari pengukurnya pengukur stabilitas dan konsistensi suatu instrument.

3. Melakukan uji asumsi klasik digunakan untuk memberikan kepastian bahwa persamaan regresi yang didapatkan memiliki dalam estimasi, konsisten dan tidak bias. Uji asumsi klasik yang diganakan dalam penelitian ini yaitu uji multikolinearitas, heteroskedastisitas dan normalitas.

4. Membuat analisis regresi sederhana dengan tujuan untuk mengetahui pengaruh dari suatu variabel terhadap variabel lainnya.

5. Melakukan uji hipotesis yang bertujuan untuk menentukan apakah dugaan yang telah dibuat mengenai karakterisik suatu populasi didukung oleh informasi yang diperoleh dari data obesrvasi atau tidak. Dalam penelitian ini uji hipotesis dilakukan untuk jawab dugaan yang telah dibuat yaitu mengenai 
pengaruh penggunaan media whatsapp terhadap kinerja karyawan.

\section{PEMBAHASAN}

Pengumpulan data dilakukan pada bulan April sampai dengan September 2020. Kuisioner dibuat dalam bentuk google form dan disebar secara online melalui media whatapps. Selama dalam kurun waktu tersebut kuisioner yang didapat sebanyak 70 responden.

Pada penelitian ini, pembahasan statistik deskriptif dibagi dalam dua bagian. Pertama, pembahasan statistik deskriptif dilakukan untuk menjelaskan dan menggambarkan berbagai karakteristik responden secara keseluruhan berdasarkan usia, jenis kelamin, jabatan, lama bekerja dan Pendidikan terakhir. Kedua, pembahasan deskriptif juga dilakukan untuk mengetahui sebaran jawaban responden dan seberapa jauh variasi jawaban responden dari setiap variabel penelitian ini.

\subsection{Karakteristik Responden}

Adapun yang menjadi responden dalam penelitian ini adalah sebanyak 70 orang dapat dilihat pada tabel 1 .

Tabel 1. karakteristik Responden

\begin{tabular}{|l|c|}
\hline \multicolumn{1}{|c|}{ Karakteristik } & Jumlah \\
\hline $24-29$ & \\
$30-35$ & 5 \\
$36-41$ & 8 \\
$42-47$ & 28 \\
$48-53$ & 15 \\
$54-59$ & 9 \\
\multicolumn{1}{|c|}{$60-65$} & 3 \\
& 2 \\
\hline Jenis Kelamin & 29 \\
Laki-laki & 41 \\
Perempuan & \\
\hline Jabatan : & 50 \\
Dosen & 20 \\
Tendik & \\
\hline Lama Bekerja : & 22 \\
$0-10$ tahun & 31 \\
10-20 tahun & 17 \\
Lebih dari 20 tahun & \\
\hline Pendidikan terakhir : & 4 \\
D3 & 10 \\
S1 & 50 \\
S2 & 6 \\
S3 & \\
\hline
\end{tabular}

Jika dilihat dari karakteristik responden yang ada dalam penelitian ini dapat dilihat bahwa yang mengisi kuisioner secara online berusia $36-41$ tahun dan didominasi oleh perempuan. Sedangkan untuk jabatan lebih banyak diisi oleh dosen dengan lama bekerja selama 10 - 20 tahun dengan pendidikan S2.

\subsection{Uji Validitas dan Reabilitas}

1. Uji Validitas

Berdasarkan hasil uji validitas yang telah dilakukan dapat dilihat Corrected Item-Total Correlation memiliki angka $\geq 0,3$ sehingga dapat dinyatakan bahwa setiap item pertanyaan yang diajukan dalam kuisioner mampu mewakili apa yang menjadi tujuan dalam penelitian ini sehingga dapat dikatakan uji yang dilakukan memiliki validitas yang tinggi, dapat dilihat pada tabel 2 .

Tabel 2. Uji Validitas

\begin{tabular}{|l|c|c|r|r|}
\hline & $\begin{array}{c}\text { Scale } \\
\text { Mean if } \\
\text { Item } \\
\text { Deleted }\end{array}$ & $\begin{array}{c}\text { Scale } \\
\text { Variance } \\
\text { if Item } \\
\text { Deleted }\end{array}$ & $\begin{array}{c}\text { Corrected } \\
\text { Item-Total } \\
\text { Correlation }\end{array}$ & $\begin{array}{c}\text { Cronbach's } \\
\text { Alpha if } \\
\text { Item } \\
\text { Deleted }\end{array}$ \\
\hline Item1 & 51.1571 & 77.352 & .782 & .948 \\
Item2 & 51.2286 & 76.875 & .809 & .947 \\
item3 & 51.2571 & 78.223 & .764 & .949 \\
item4 & 51.1571 & 77.265 & .789 & .948 \\
item5 & 51.1571 & 76.685 & .813 & .947 \\
item6 & 51.5286 & 77.267 & .798 & .948 \\
item7 & 51.5000 & 76.428 & .814 & .947 \\
item8 & 51.2286 & 76.556 & .814 & .947 \\
item9 & 52.0571 & 75.475 & .699 & .951 \\
item10 & 52.0286 & 75.448 & .674 & .952 \\
item11 & 51.8000 & 75.786 & .758 & .949 \\
item12 & 51.7000 & 76.648 & .663 & .952 \\
item13 & 51.6286 & 73.106 & .809 & .947 \\
\hline
\end{tabular}

2. Uji Reabilitas

Berdasarkan hasil uji yang telah dilakukan khususnya mengenai uji reabilitas yang menghasilkan angka cronbanh's alpha sebesar 0,952 dimana angka ini lebih dari 0,7 sehingga dapat dinyatakan bahwa pertanyaan dalam kuisinoer menghasilkan pengukuran realibel. Hal ini mengandung arti bahwa pengukuran yang dilakukan dalam kuisioner dapat dipercaya dan memiliki tingkat kestabilan yang baik sehingga ketika dilakukan pengukuran kembali maka akan dapat diperoleh hasil yang relatif sama dijabarkan pada tabel 3 .

Tabel 3. Uji Reabilitas

\begin{tabular}{|r|r|}
\hline \multicolumn{2}{|c|}{ Reliability Statistics } \\
\hline Cronbach's Alpha & N of Items \\
\hline .952 & \\
\hline
\end{tabular}

\subsection{Uji Asumsi Klasik}

1. Multikolinearitas

Hasil uji multikolinearitas yang telah dilakukan terlihat variabel independen tidak memiliki nilai tolerance kurang dari 0,10 dan hasil perhitungan Variance Inflation Factor (VIF) juga tidak menunjukkan nilai VIF lebih dari 10. Maka dapat disimpulkan bahwa model regresi yang diajukan bebas dari multikolinearitas. Begitu pula dengan masing-masing indikator pada variabel independen dapat disimpulkan bebas dari multikolinearitas. 
2. Uji Normalitas

Hasil pengujian dengan analisis grafik plot pada gambar 1, menunjukkan bahwa model regresi terdistribusi normal, karena titik-titik menyebar di sekitar diagonal serta penyebarannya mengikuti arah diagonal.

\section{Normal P.P Plot of Regression Standardized Residual}

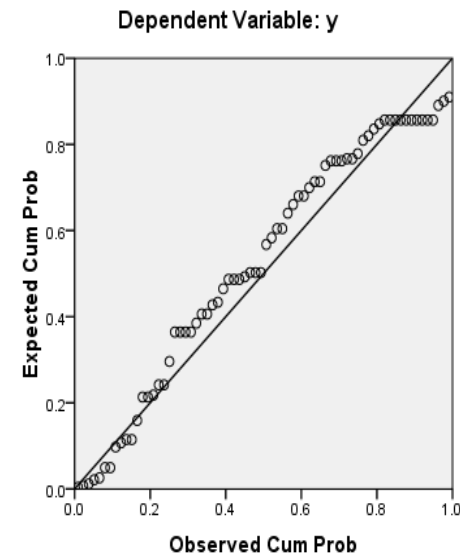

Gambar 1. Uji Normalitas

\section{Uji Heteroskedastisitas}

Dari output gambar 2, dapat diketahui bahwa titiktitik tidak membentuk pola yang jelas, dan titik-titik menyebar di atas dan di bawah angka 0 pada sumbu Y. Jadi dapat disimpulkan bahwa tidak terjadi masalah heteroskedastisitas dalam model regresi.

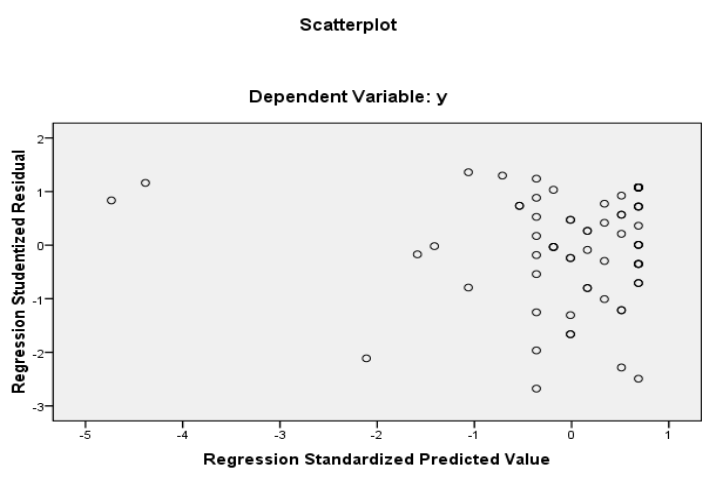

Gambar 2. Uji Heteroskedastisitas

\subsection{Analisis Regresi Sederhana}

Analisis regresi sederhana pada tabel 4, dapat digunakan untuk mengetahui arah dari hubungan antara variabel bebas dengan variabel terikat, apakah memiliki hubungan positif atau negatif serta untuk memprediksi nilai dari variabel terikat apabila nilai variabel bebas mengalami kenaikan ataupun penurunan.
Tabel 4. Analisis Regresi Sederhana

\begin{tabular}{|c|c|c|c|c|c|}
\hline \multicolumn{6}{|c|}{ Coefficients $^{a}$} \\
\hline \multirow[b]{2}{*}{ Model } & \multicolumn{2}{|c|}{$\begin{array}{l}\text { Unstandardized } \\
\text { Coefficients }\end{array}$} & \multirow{2}{*}{$\begin{array}{c}\begin{array}{c}\text { Standardized } \\
\text { Coefficients }\end{array} \\
\text { Beta }\end{array}$} & \multirow[b]{2}{*}{$\mathrm{t}$} & \multirow[b]{2}{*}{ Sig. } \\
\hline & B & Std. Error & & & \\
\hline \multirow{2}{*}{1 (Constant } & -.142 & .400 & & -.356 & .723 \\
\hline & .897 & .094 & .757 & 9.568 & .000 \\
\hline \multicolumn{3}{|c|}{ a. Dependent Variable: kinerja } & & & \\
\hline
\end{tabular}
(1)

Berdasarkan tabel di atas dapat maka dapat diperoleh

$$
\mathrm{Y}=-0,142+0,87
$$

Konstanta sebesar -0,142; artinya jika penggunaan whatsapp (X) nilainya adalah 0 , maka kinerja karyawan (Y') nilainya negatif yaitu sebesar $-0,142$. Variabel penggunaan whatsapp berpengaruh positif terhadap kinerja karyawan sebesar 0,897 dengan tingkat signifikansi 0,00 yang mengandung pengertian bahwa setiap terjadi kenaikan pada kinerja karyawan 1 satuan maka kinerja karyawan akan naik sebesar 0,897.

\subsection{Uji Koefisien Determinasi}

Berdasarkan hasil pengujian dengan menggunakan alat bantu SPSS diketahui bahwa kinerja karyawan dipengaruhi penggunaan whatsapp sebesar $57.4 \%$ (R Square) sedangkan sisanya dipengaruhi oleh faktor lain yang tidak dijelaskan dalam penelitian ini, hal ini dapat dilihat pada tabel 5 .

Tabel 5. Uji Koefisien Korelasi

\begin{tabular}{|c|c|c|c|c|c|}
\hline Model & $\mathrm{R}$ & R Square & $\begin{array}{c}\text { Adjusted } \\
\text { R Square }\end{array}$ & $\begin{array}{c}\text { Std. } \\
\text { Error of } \\
\text { the } \\
\text { Estimate }\end{array}$ & $\begin{array}{c}\text { Durbin- } \\
\text { Watson }\end{array}$ \\
\hline 1 & $.757^{\mathrm{a}}$ & .574 & .568 & .62631 & 2.279 \\
\hline
\end{tabular}

\subsection{Uji Hipotesis}

Berdasarkan hasil uji yang telah dilakukan dapat dilihat pada tabel 4, menunjukkan bahwa tingkat signifikansi pada penggunaan whatsapp berada pada 0,000 dimana nilai ini dibawah ini nilai 0,05 yang menyatakan bahwa adanya pengaruh penggunaan whatsapp terhadap kinerja karyawan. Whatsapp merupakan salah satu media yang sering digunakan sehingga mudah untuk memahami dan dapat mempermudah dalam menjalin hubungan serta penggunaan whatsapp lebih ekonomis dibandingkan aplikasi lainnya.

Penyampaian informasi menggunakan whatsapp lebih cepat sehingga mudah untuk melakukan koordinasi khususnya mengenai pekerjaan yang harus dilakukan. Penggunaan whatsapp ini dirasakan sangat bermanfaat untuk karyawan khususnya dalam keadaan pandemi covid-19 ini dimana kegiatan yang terkait dengan pekerjaan tetap harus dilakukan walaupun tidak 
dilakukan secara langsung. Politeknik Negeri Samarinda di saat seperti ini melakukan pembelajaran secara daring sehinga dosen dan mahasiswa menggunakan whatsapp sebagai sarana berkomunikasi secara virtual. Di samping itu dosen dan tenaga kependidikan memiliki kewajiban untuk melaporkan kegiatan/pembelajaran daring kepada atasannya dimana salah satu media yang paling efektif digunakan adalah whatsapp, walaupun tidak bertatap muka secara langsung tetapi koordinasi tetap bisa berjalan sesuai dengan kondisi pandemi sekarang ini. Hal ini dilakukan agar kegiatan/pembelajaran daring tetap bisa dimonitoring dan dievaluasi oleh pihak terkait.

\section{KESIMPULAN}

Berdasarkan hasil uji yang telah dilakukan menunjukkan bahwa penggunaan media whatsapp memiliki pengaruh terhadap kinerja karyawan/pegawai yang ada di Politeknik Negeri Samarinda. Hal ini dapat dilihat dari segi pengetahuan, penggunaan dan manfaat dimana dengan adanya aplikasi ini mempermudah dalam melakukan koordinasi dalam hal melakukan pekerjaan, tanpa harus bertatap muka secara langsung informasi dapat tersampaikan dengan cepat efisien. Hal ini juga tak lepas dari kondisi pandemi yang mewajibkan untuk tetap menggunakan protokol Kesehatan sehingga dengan adanya aplikasi ini sangat mempermudah dalam melakukan segala aktivitas yang terkait dengan pekerjaan.

\section{SARAN}

Pada dasarnya penelitian yang telah dilakukan hanya menggunakan satu variabel bebas maka dalam penelitian selanjutnya dapat menambahkan atau menggunakan lebih dari satu variabel bebas serta analisis yang digunakan juga masih tergolong sederhana dikarenakan hanya menggunakan dua variabel saja dalam penelitian ini. Selain itu, penelitian selanjutnya dapat dilakukan tidak hanya terfokus pada satu tempat saja namun dapat dilakukan di beberapa tempat sehingga dapat dibandingkan hasilnya, dimana hasil penelitian yang akan dihasilkan nantinya dapat dijadikan sebagai bahan masukan untuk menciptakan kinerja karyawan yang lebih baik lagi.

\section{DAFTAR PUSTAKA}

Afandi, P. 2018. Manajemen Sumber Daya Manusia (Teori, Konsep dan, and Indikator). Riau: Zanafa Publishing.

Anjani, A., Ratnamulyani, I. A., \& Kusumadinata, A. A. 2018. Penggunaan Media Komunikasi Whatsapp terhadap Efektivitas Kinerja Karyawan. Jurnal Komunikatio, 4(1).

Arifianto CJ. 2017. Komunikasi Di Era Digital. Jakarta.

Arifin, H. F. 2015. Pengaruh whatsapp terhadap perilaku tertutup mahasiswa (survey pada mahasiswa ilmu komunikasi fishum universitas islam negeri sunan kalijaga yogyakarta angkatan 2014). Yogyakarta
(ID): Program Studi Ilmu Komunikasi FISHUM Universitas Islam Negeri Sunan Kalijaga.

Bernardin \& Russel. 2016. Pintar Manajer, Aneka Pandangan Kontemporer, Alih Bahasa Agus Maulana. Jakarta: Binarupa Aksara.

Jati, P. P. 2016. Analisis Pengaruh Aplikasi Whatsapp terhadap Kinerja Karyawan pada PT. First Position Group. Pengaruh, Anal. Whatsapp, Apl. Kinerja, Terhadap Pada, Karyawan.

Kusuma, A. C. 2013. Analisis Pengaruh Komunikasi Efektif terhadap Kinerja Karyawan PT. Mitra Makmur Industri. Alih Jenis Manajemen. Bogor: Institut Pertanian Bogor.

Nitisusastro, M. 2012. Perilaku Konsumen dalam Perspektif Kewirausahaan. Bandung: Alfabeta.

Rofano, E. C. 2019. Pengaruh Penggunaan Teknologi Informasi, Kompleksitas Tugas, Dan Lingkungan Kerja Terhadap Kinerja Pegawai. Jurnal Ekonomi Dan Kewirausahaan, 18(4).

Rusni, A., \& Lubis, E. E. 2017. Penggunaan Media Online Whatsapp Dalam Aktivitas Komunitas One Day One Juz (Odoj) Dalam Meningkatkan Minat Tilawah Odojer Di Kota Pekanbaru (Doctoral dissertation, Riau University).

Sihombing, M. U. 2017. Mega Pengaruh Komunikasi Melalui Grup Whatsapp Untuk Meningkatkan Kinerja Karyawan Di Hotel Grandhika Medan. Jurnal Lensa Mutiara Komunikasi, 1(1), 33-42.

Sugiyono. 2012. Metode Penelitian Kuantitatif, Kualitatif Dan R\&D. Bandung: Alfabeta.

Sukrillah, A., Ratnamulyani, I. A., \& Kusumadinata, A. A. 2018. Pemanfaatan Media Sosial Melalui Whatsapp Group Fei Sebagai Sarana Komunikasi. Jurnal Komunikatio, 3(2).

Wahyuni, Y. L. 2016. Efektifitas Komunikasi Melalui Aplikasi Whatsapp (Studi Terhadap Group KPI 2012 Di Whatsapp Pada Mahasiawa KPI Angkatan 2012). Yogyakarta (ID): Universitas Islam Negeri Sunan Kalijada Yogyakarta. 